ISSN 2236-0859

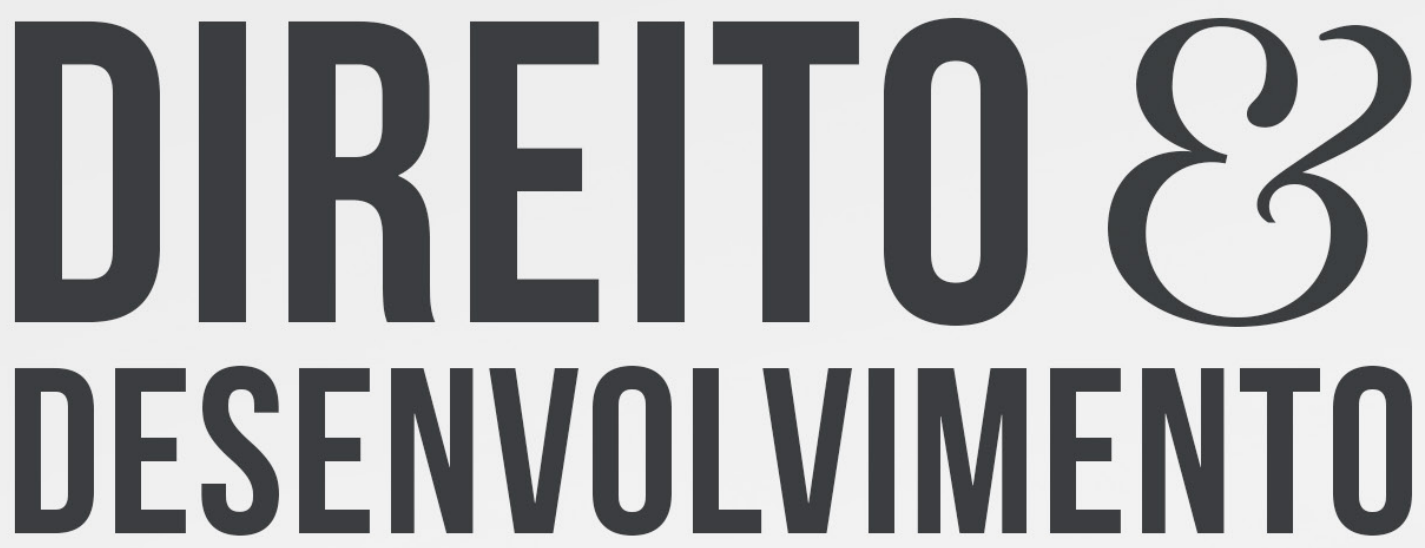

REVISTA DO PROGRAMA DE PÓS-GRADUAÇÃO EM DIREITO MESTRADO EM DIREITO E DESENVOLVIMENTO SUSTENTÁVEL

LEGAL ASPECTS OF TECHNICAL ASSISTANCE IN URBAN LANDHOLDING REGULARIZATION PROVIDED FOR IN THE BRAZILIAN LAW 11888/2008 ANDITS IMPACT IN THE STATE OF PARAÍBA, BRAZIL

GEORGE BARACUHY CRUZ VIANA

EDSON RICARDO SALEME 


\title{
LEGAL ASPECTS OF TECHNICAL ASSISTANCE IN URBAN LANDHOLDING REGULARIZATION PROVIDED FOR IN THE BRAZILIAN LAW 11888/2008 AND ITS IMPACT IN THE STATE OF PARAÍBA, BRAZIL
}

\section{ASPECTOS JURÍDICOS DE ASSISTÊNCIA TÉCNICA NA REGULARIZAÇÃO URBANA DE TERRENOS PREVISTOS NA LEI BRASILEIRA 11888/2008 E SEU IMPACTO NO ESTADO DE PARAÍBA, BRASIL}

Received: $17 / 10 / 2019$

Approved: 13/12/2019
George Baracuhy Cruz Viana ${ }^{1}$ Edson Ricardo Saleme ${ }^{2}$

\begin{abstract}
:
This paper analyzes the role of the state in its mission of ensuring the existence of sustainable cities with adequate housing and meeting the standards set by current legal dictates. For this purpose, firstly, the right to housing guaranteed by the current Constitution, in its article 6 caput, is assessed as one of the most basic needs of the individual, considered a fundamental right since 1948 by the Universal Declaration of Human Rights. This paper also investigates the guarantee of decent housing for the citizen is effective, as provided for in the City Statute, Law No. 10257, 2001, especially with the publication of Law n. 11.888 /2008, which guarantees free public assistance in the project and construction of social housing for low-income families. This rule regulates the hiring of professionals who, while preserving their urban legislation, ensure compliance with an adequately sustainable environment. This article will use the hypotheticaldeductive method and the bibliographic research methodology.
\end{abstract}

Keywords: Technical assistance. Law n. 10.257/2001. Law n.11.888/2008. Sustainable cities. Right to housing.

(JEL) R52 - Land Use and Other Regulations

\section{RESUMO:}

Este artigo analisará o papel do Estado em sua missão de garantir a existência de cidades sustentáveis com moradias adequadas e que atendam aos padrões estabelecidos pelos atuais ditames legais. Para tanto, em primeiro lugar, avalia-se aqui o direito à moradia, garantido pela atual Constituição, em seu artigo 6o caput, como uma das necessidades mais básicas do indivíduo, considerado um direito fundamental desde 1948, pela Declaração Universal de

1 Mestrando em Direito Ambiental pela Universidade Católica de Santos. Pós-Graduado em Direito Eleitoral pela Escola Superior da Advocacia de Pernambuco - ESA-PE (2015). Email: gbcviana@hotmail.com

2 Doutor em Direito do Estado pela Universidade de São Paulo (1998). Atualmente é professor permanente do Curso stricto sensu (Mestrado e Doutorado) em Direito Ambiental Internacional na Universidade Católica de Santos, líder do Grupo de Pesquisa Direito Ambiental das Cidades.. Na graduação leciona na Unisantos e na Universidade Paulista ; professor de especialização da Escola Superior do Ministério Público de São Paulo, do IPOG, INOREG e Notável. Email: ricasal@uol.com.br 
Direitos humanos. Em seguida, aqui se investiga como se efetiva a garantia de moradia digna

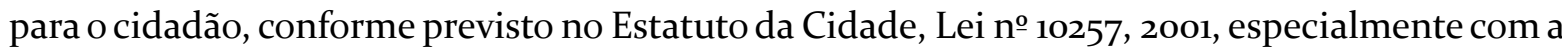
publicação da Lei no 11.888 /2008, que garante assistência pública gratuita no projeto e construção de moradias de interesse social para famílias de baixa renda. Essa regra regula a contratação de profissionais que, ao mesmo tempo em que preservam a respectiva legislação urbana, garantem a conformidade com um ambiente adequadamente sustentável. Este artigo utilizará o método hipotético-dedutivo e a metodologia de pesquisa bibliográfica.

Palavras-chave: Assistência técnica. Lei 10.257/2001. Lei 11.888/2008. Cidades sustentáveis. Direito à moradia.

\section{INTRODUCTION}

Living goes beyond residing. The act of residing also comprises the place where the individual keeps his intimacy and his private relationships, in addition to develop his family life. The right to housing is broad and includes interpretations that escape a single focus analysis.

The right to a physical space, limited by the dimensions of the property, is the most primitive conception offered to the idea of "housing". Its recognition in several developments is the result of relevant achievements in different aspects of extralegal nature. The problems surrounding the theme are numerous and have been the subject of fierce discussions including the housing deficit and landholding exclusion, among many others, existing not only in Brazil, but all over the world, and depending upon the direct action of the State, such as social programs, public policies, policy publishing and administrative acts, to make existing legal provisions tangible.

Given the essence of the right to housing, since it is inherent in the most common needs of man, the search for its fulfillment is of paramount importance. This is really fundamental for this right to be conceived in its entirety, as the right to housing unfolds into other constitutional guarantees and derives from relevant constitutional principles. Based on this this statement, the representative to the Constitutional Convention set forth articles 182 and 183 in order to establish key-points at Chapter II of Title VII from Brazilian Federal Constitution, which address urban policy.

The legal provisions abovementioned were regulated by Law No. 10257 from 2001, which inaugurated a series of regulations with urban content and innovative formulas in terms of the social function of property, decent housing for less affluent social classes, urban mobility, municipalities with high rainfall and possibility of landslides, among other aspects that are filling essential gaps in terms of individual and collective interests. ${ }^{3}$

There are also other elements being considered regarding occupation of real estate for housing purposes, such as urban issues (own infrastructure), appropriate urban mobility road system, concern for environmental issues and so many other rights and guarantees to be properly secured.

In this sense, the aforementioned Law n. 10.257, of 2001, called the City Statute, established in art. 2, III, as one of its general guidelines, "the cooperation between governments, private initiative and other sectors of society in the process of urbanization, in order to meet

3 In addition to the City Statute (Law No. 10257 of 2001) we can mention: Law No. 12587 of 2012 (Urban Mobility); Law No. 12608 of 2012 (Lei do Sistema Nacional de Proteção e Defesa Civil, a Brazilian law establishing a national system for protection and civil defense); Law No. 11977, 2009 (Minha Casa Minha Vida, a Brazilian government housing programme) and Law No. 13465, 2017, which provided for urban landholding regularization. 
social interest"; rules directed to the use of urban property for the collective good, in addition to citizens safety and welfare, taking into account the important environmental balance. List in its art. 4, among legal and political institutes, sub-paragraph V, " $r$ ", the "free technical and legal assistance for less privileged communities and social groups."

In order to comply with the social right to housing provided for in art. 6 of the Brazilian Constitution, and considering the provisions of the clause " $r$ ", sub-paragraph V, art. 4, caput, of Law n. 10.257 of 2001, which regulates the articles 182 and 183 from the Federal Constitution, the Law n. 11.888, of 2008, was published, assuring low-income families free public technical assistance for the design and construction of their first habitations.

According to José dos Santos Camargo Filho (2013, p. 86), there are two types of assistance: one is the technical assistance, which provides information and technical assistance for architectural housing projects, and the other is the legal assistance, which ensures the provision of information and legal guidance capable of providing advice to this part of the population that does not have access to these data.

This set of urban regulations assures the materialization of technical assistance concerning the right to housing, as can be understood from the reading of the legal provisions. They are not programmatic or ineffective regulations. Its provisions aim at the rational use and harness of the built area and its surroundings. It also provides for the use of human, technical and financial resources to be employed in building design and construction. These are services which, according to the art. 3, caput, of the regulation, are "permanent and free services of technical assistance in architecture, urban planning and engineering."

Is it possible to state, therefore, that housing public policies are effectively attentive to the provisions of Law n. 11.888 of 2008 ? Are there currently free technical assistance services in architecture, urban planning, engineering and landholding regularization of housing?

This paper will investigate whether there is, in fact, compliance with these regulations, a result of arduous social struggles, with a view to the realization of the right to housing and the required assistance. To that end, it will be conducted a search for legislation, documents, political analyzes and articles on the subject in the specialized bibliography. The deductive method of approach was applied, starting from a broad perspective, that is, the right to housing guaranteed in Brazilian Constitution, to address the theme more specifically: the performance of Brazil, through the publishing of Law n. 11.888 of 2008 , as a way of securing this right in a safe and dignified manner.

\section{THE RIGHT TO HOUSING AS A SOCIAL RIGHT}

The Brazilian Federal Constitution, in its article 6, lists the right to housing as a constitutional guarantee of social nature, being on the same level as the right to health, safety, protection of motherhood and childhood, assistance to helpless people, to work, leisure, social security and other rights assured there.

Initially absent in the body text of Article 6 from the Constitution, the right to housing is considered a social guarantee. Later, through Constitutional Amendment No. 26 of February 14, 2000, it became expressly stated. The correction of this constitutional omission was taken for granted, since its absence was already observed in several provisions and its text, indirectly, already referred to the right to housing as something always present, namely: Article 7 , which address the right of workers to have an income capable of financing their most basic consumption, including housing; Article 21, sub-paragraph XX, and Article 23, sub-paragraph 
IX, which address the jurisdictions for promoting housing programs; and Article 183, which, in turn, already provided for housing, when dealing with adverse possession.

Considering the present legislation (LEMOS JR and OLIVEIRA) about right of housing it should be considered that [...] in the area of development, between wealth and poverty and development and underdevelopment, the various countries necessarily reflect the possibilities of each one to offer a justice system [...] in the form of legislations.

The protection of the right to housing is inherent in the principle of dignity of human person, since there is only a dignified life if there are appropriate conditions to keep the minimum standards for maintaining habitability.

It should be noted that, in addition to these guarantees, Brazil is a signatory to several international agreements that, when the Constitutional Amendment 26/2000 was created, guaranteed the right to housing. Other signatory states have already been obliged to guarantee several rights including decent housing.

Regarding these international acts, the Universal Declaration of Human Rights of 1948 stands out, once its article XXV already states that:

Everyone has the right to a standard of living adequate for the health and well-being of himself and of his family, including food, clothing, housing and medical care and necessary social services, and the right to security in the event of unemployment, sickness, disability, widowhood, old age or other lack of livelihood in circumstances beyond his control (UDHR, 1948).

This fundamental right was included in other international documents, such as the International Covenant on Economic, Social and Cultural Rights, promulgated by Decree $\mathrm{n}$. 591 of July 6,1992 . In its article 11, it states that member states recognize the right to decent housing and encourages the adoption of public policies:

The States Parties to the present Covenant recognize the right of everyone to an adequate standard of living for himself and his family, including adequate food, clothing and housing, and to the continuous improvement of living conditions. The States Parties will take appropriate steps to ensure the realization of this right, recognizing to this effect the essential importance of international co-operation based on free consent (Decree n.591, 1992).

Article 3 establishes that "The States Parties to the present Covenant undertake to ensure the equal right of men and women to the enjoyment of all economic, social and cultural rights set forth in the present Covenant."

The International Covenant on Economic, Social and Cultural Rights was one of the main international documents that favored the explicit inclusion of the right to housing in the current Constitution. The effectiveness of this right requires considerable budgetary efforts and political will in this regard, since its implementation must involve several elements, among which the acquisition of adequate area for the inclusion of urban equipment.

Among the important instruments ratified by Brazil contributing to the accomplishment of this important task of materializing the right to housing, one can list directly: Agenda 21 on the Environment and Development; the Vancouver Declaration on Human Settlements; the Istanbul Declaration on Human Settlements, together with the Habitat Agenda, resulting from the second United Nations Conference on Human Settlements, held in 1996 in Istanbul, Turkey. Also, the Convention on the Elimination of All Forms of Racial Discrimination; the Elimination of All Forms of Discrimination against Women; Convention on the Rights of the Child, which address, even indirectly, the right to decent housing. 
The Brazilian Constitution, Justice and Drafting Commission (Comissão de Constituição, Justiça e Redação), in its report from 2018, has corroborated the influence of manifestations guaranteeing the right to housing that occurred internationally, it is possible to see the importance and relevance of the subject being discussed:

\footnotetext{
The matter referring to the right to housing has been the object of access to polarized social debate at both national and international levels. Forums, trade associations, governmental and non-governmental entities have been meeting in recent years to prepare for the largest meeting ever on the topic: the Habitat II Conference convened by the United Nations (UN) and held from June 3 to 14, 1996.

For this event, Brazil was appointed rapporteur for the Habitat Agenda (conference letter of intent) addressing the "right to housing." Brazil had the difficult task of justifying, with regard to countries such as Japan, United States and Korea (which are contrary to the inclusion of this term on the agenda), the urgent need to recognize housing as a social right. Brazilian active participation in such an important worldwide event puts us in a delicate position, especially when there is, in the midst of an eminently critical situation in Brazilian urban areas, a gap in the Federal Constitution itself, which does not recognize housing as a real right, such as health, leisure, work, etc. Even more delicate is the situation in Brazil when, having heard about the Conference, "homeless" from all over the country, already well organized, threaten to "increase land occupations" on the outskirts of large cities - as one reads in the most renowned newspapers from the country.

The current housing conditions of thousands of Brazilians are depressing and constitute a real "social sore" for most of the country's metropolises. Therefore, it is urgent to start a process of recognition of housing as a basic cell, from which are developed other citizen rights, already recognized by our Constitution: the right to health, work, safety, leisure, among others. Without housing, the individual loses his identity, essential to the development of his activities as a social and productive being, impoverishing and becoming marginalized. With him, invariably impoverishes the Nation. (CCJ, 2019)
}

Brazilian law includes the issue of right to housing in the field of social rights. Considering the problems the country faces and the size of its territory, it must guarantee housing, eradicate poverty and guarantee the dignity of the human person. All these commitments are imposed by regulations as fundamentals and principles the country must comply with promptly. They are recognized as immediately applicable, as indicated in the text of art. 5, paragraph 1 , of the Brazilian Federal Constitution.

It is relevant what Benacchio and Cassetari (2014; p.48-71) asserted, when they stated that the human right to housing is not only realized through the assignment of right to property. There may be other situations legitimizing the use of physical space for this purpose, such as renting and social rent, use of collective spaces, among other modalities intended for the legal security of the occupation.

Brazil has continental dimensions and relevant justifications to not comply with some obligations, such as unfavorable weather conditions, accessibility, size, poverty, among others, and to the problems of social nature it faces. Social inequality, due to the absence of effective public policies, coupled with globalization, which aggravates the issue of poverty, contribute to the housing problem in both urban and rural areas.

Given this problem, it is really true what NALINI (2014, p. 3-10) states about the fact that ensuring housing for all its inhabitants is one of the biggest challenges of the metropolises. The author still states that "[...] the phenomenon of urbanization was not planned. A few decades ago, most Brazilians lived in the countryside."

The author goes on, saying that there is no shortage of laws. The problem is eminently cultural: if the guiding principle of the Constitution is the dignity of the human person and 
it promises welfare, development, equality and justice as supreme values, other regulations, among them the City Statute, which detailed all these housing principles, there is no doubt that what is lacking to its materialization is "will and courage".

Another important aspect, noted by TORRES (2009, p. 192), is the question: is housing a social or fundamental right? The answer given by the jurist is that for homeless and homeless housing, it is a fundamental right. It is part of the existential minimum, and the obligation of the State must be inexorable regarding its fulfillment. In turn, popular housing or even middle-class housing, which becomes social rights dependent on subsequent public policies are seen under a different light.

In this sense, Brazil has made commitments of great responsibility, through its representatives and also by the international acts it has signed. Undoubtedly, fulfilling these commitments is a complex task and involves a great number of conditions, not always favorable. However, it can be said that the right to housing, although guaranteed, is not limited to the assignment of property. There are other less onerous ways to fulfill national commitments without compromising the budget, what would cause even greater damage to the public purse.

\section{THE ROLE OF THE STATE AS GUARANTOR OF THE FUNDAMENTAL RIGHT TO HOUSING AND THE PROVISIONS OS THE ADVISODRY TEAMS TO THOSE IN NEED UNDER LAW N. 11.888, OF 2008}

One of the most relevant conferences on urban planning, where the issue regarding the challenge of cities was addressed, took place in Athens in 1933 (2019). In the conference were discussed the problems of cities, the dilemmas faced in terms of planning and the necessary perception that cities should have a social function. The Athens Charter identified four essential functions of urban planning: the right to healthy housing, the organization of workplaces, the provision of appropriate leisure facilities, and finally, the establishment of a contact networking of these various organizations to assure exchanges.

Then, arose the latent concern on the part of the State on how to solve the need to provide "healthy housing" in the face of the complex situation of homeless people, irregular land occupations of the most diverse kinds, or even following what the cities master plan prescribes, object of municipal law.

It is important to emphasize that the occupations occur, most of the time, through invasions and occupations, which causes the action of the public authorities occur in the background, or rather, a posteriori. It is true that the properties that disrespect environmental or urban legislation reflect the absence of the Government due to the lack of public policies aimed at ensuring the fulfillment of this social need in a correct way.

The UN Committee on Economic and Social Rights (2019), according to the 2014 report, regarding Brazil's contribution to fulfill international housing provisions, noted that the country's commitment to "urbanization of precarious settlements" should provide "construction works and services or adaptation of housing units and implementation of basic infrastructure". This comprises power grid, public lighting, water supply, sewage, rainwater drainage and solid waste collection and conditioning.

Interestingly, there was the provision to "present a participatory project on social work whose scope would allow investments in the construction of social facilities, and actions to support community organization, environmental preservation and professional qualification, among others." 
Initiatives to make social housing available could be seen in the Law n.. 11.977, of 2009, which already provided for the program of regularization of land ownership, making possible the regularization of sustainable land in order to implement legal projects and also projects for environmental urbanization in these places.

Law n. 13.465, of 2017, also created a similar provision. There is a tendency in Brazilian legislation to guarantee the right to housing, without unbridled disrespect for urban planning legislation, by not following regulations established by various zoning laws or even disregard the master plan, if any.

The Law n. 11.888, of 2008, known as the Technical Assistance Law, addressed the guarantee of social right to housing, constitutionally provided for in clause " $r$ " from subparagraph V of art. 4, caput, from the Law no. 10.257, of 2001, in order to enable the provision of these necessary services by trained professionals in the construction of housing for lowincome population. The process also offers an assistance to obtain licenses to build, renovate or expand housing with the municipal government and other public agencies; it also avoids occupation in areas under environmental risk, and interventions assure compliance with urban and environmental legislation.

The Law also provides for participatory aspects, incorporating the communities' own efforts and their organizational capacity to the housing policy. Thus, initiatives initiated under a joint effort in areas declared as being of social interest or in areas declared by law as being of social interest are prioritized. The financial aspect must be backed up through Union's financial support to States, Federal District and municipalities in order to provide free and permanent technical assistance services in architecture, urban planning and engineering. Paragraph 1 of art. 3 of the Law clarify that "Technical assistance may be offered directly to families or to cooperatives, neighborhood associations or other organized groups representing them."

The struggle to assure such a guarantee lasted nearly thirty years. Initially, in 1976, architects trade unions from the State of Rio Grande do Sul, in partnership with the Regional Council of Architects and Engineers, devised a program called "Technical Assistance to Affordable Housing", aimed at the neediest population; in 1995, in Porto Alegre, the first bill to ensure technical assistance in Brazil was presented, aiming to guarantee free technical assistance in housing construction for those most in need, coming into force in 1999; in 2002, shortly after publishing the Constitutional Amendment guaranteeing the right to housing as a constitutional right in Porto Alegre, this change had a positive impact and there began studies to cover the entire Brazilian territory, culminating in the submission of Bill No. 6223/2002, in 2005, at the I Seminário Nacional de Assistência Técnica (I National Seminar of Technical Assistance). That bill has undergone some changes. In 2006, after the II Seminário Nacional de Assistência Técnica (II National Seminar of Technical Assistance) in 2019, the Law was finally approved; and at last, in 2008, Law No. 11888 of 2008 was enacted.

The Law has a set of players and measures that, through proper coordination, can enable assistance. The regulation became effective as of July 2009 and enabled the element that really lacked in current housing programs: direct technical assistance to each family or even to the same family group. First, it is necessary search for a professional among those registered in some professional class entity. The municipality, through its executive branch, will register the beneficiaries receiving the assistance. This agency should also seek the required resources in order to pay this assistance, as referred to in art. 3. All these actions, especially registration, should be widely publicized so that everyone can be aware of what will be available.

It is possible here to mention the collaborative platform originated in the Forum of Technical Assistance and University Extension Program on Social Interest Housing: Integrated Actions in Urban Space" (ATHIS- 2019). This project was selected in the Public Call Notice n. 
002/2018, administrative process n. 021/2018 from the Council of Architecture and Urbanism - São Paulo (CAU / SP). In this project was established a partnership between students from Architecture and Urbanism Colleges of São Paulo Metropolitan Area, Brazilian Institute of Architects - São Paulo Department (IABsp) and FAU Mackenzie.

Regarding the resources to make the execution of the technical assistance viable, the Law, in its article 6 , states that this service must be financed by resources from federal funds directed to social-interest housing, by public budgetary resources or by private resources.

The vast majority of financing sources come from the Fundo Nacional de Habitação de Interesse Social (Brazilian National Social-Interest Housing Fund) and from municipal and state housing funds, and public agencies are responsible for managing this money, by creating social programs aimed at its implementation (2018).

The Law n. 11.888, of 2008, also encourages, in its article 4, the qualification of professionals involved in providing technical services - engineers, architects, urban planners - so that they can perform an efficient work. These professionals can include: Union, States, Federal District or Municipal public officers; non-profit and non-governmental organizations members; professionals enrolled in architecture residency programs in architecture, urban planning or engineering, or university extension programs, through model offices or public offices acting in the area; freelance professionals or members of legal entities staff, previously accredited, selected and hired by Union, State, Federal District or Municipality (2018).

Thus, it is noted that the action of the Government, in publishing the Technical Assistance Law, was a mechanism to safeguard various constitutional guarantees, as citizenship is interconnected with the right to decent housing, which has synergy with the principle of dignity of the human person and culminates in an organized and democratic city, complying with urban and environmental laws.

Even in the face of this legal provision it is possible to observe that households are undergoing constant changes made by their occupants. This is due to the fact that user needs were disregarded in the initial project. Given this situation, the presence of qualified professionals in renovations is fundamental. In document and photograph analysis made with several projects created by the Minha Casa, Minha Vida housing program, Nadia de O. Camacho (2016) noticed in her research, profound changes in housing units resulting from the occupation process over time. This fact, according to her, reinforces "the relevance of the work of civil construction professionals (architects and engineers) to ensure the highest quality of renovations / extensions within safe, legal and technical constructive parameters through Law n. 11.888, of 2008."

An achievement of this Federal Law is the possibility of excluding these houses from clandestinity and illegality. Self-construction can lead to property embargoes or demolition actions due to the risk these kind of construction presents. Real estate in which urban parameters were not followed during its construction, greatly damage public space, in addition to prevent the access of public services such as gas, water distribution, sanitation, among others.

Technical assistance and its maintenance, which applies from the project to the completion or availability of essential renovations, in the words of Souza (2000), can be considered a major advance at this time. It may seem at this moment something without much relevance. But if taken seriously, over time, it can promote well-planned, more efficient, safer, and affordable cities.

The purpose of the relevant legislation is to enable actions of public authorities through the spheres established in the current Constitution, which allows the creation of publicprivate partnerships with academic entities. Thus they can meet, improve, correct, plan, 
optimize, harness, democratize knowledge, qualitative improvement of projects, technological innovation, engineering, architecture and urbanism actions in the housing modules executed by low-income population. In this way, the creation of informal urban centers that directly offend human dignity is avoided (MORAES, 2012).

The Brazilian Institute of Architects (2010) clarifies that by allowing the provision of individual service, the Law allows the democratization of assistance services, which can be provided in a diffused and scattered way in the urban grid. It keeps families served in their social environment and in places where, in many cases, basic infrastructure and public services already exists. Given this fact, it is possible to save travel and public spending on new demands for supply, services and transport.

\section{REGULATIONS FOR HOUSING IN PARAIBA}

In the State of Paraíba, a survey conducted by Jakeline Silva Santos (2014) found that the João Pessoa City Council approved, in 2007, the Law n. 10894, 2007, which provides for the public engineering and architecture program. This regulation, as the author well points out, was not published in official news channels, which would make it unable to produce legal effects. Even then, she emphasizes that the Municipal Law protects the right to exercise technical assistance to the technicians who already are members of the João Pessoa City Hall. However, it would not include independent professionals, what is contrary to Law n. 11.888, of 2008 , which in addition to prescribe the presence of these professionals, also states that financial resources for exercising technical assistance must be released by the FNHIS, through state and municipal agreements. The author notes misconceptions and conflicts that must be overcome in the writing of a new regulation. This posture leads the researcher to conclude that the position adopted by CAU-BR and CAU-PB is disturbing, as it does not essentially stands out in terms of the social insertion of the architect in the exercise of this function. The President of CAU-PB would be attentive to this issue and, according to the author, was seeking to establish partnerships with the academies, in order to create model offices with the existing architecture and urban planning courses in the State of Paraíba. This would be in line with the provisions of Law n. 11.888, 2008, and would enable the professional residency of graduates.

What we are essentially looking for is a better quality scenario for what we have as a city in Brazil. This is not a purely visual objective. The presence of a professional should avoid continuous misunderstandings constantly occurring in the several community groups existing in the country. Perhaps what is proposed in the near future, in addition to reduce housing deficit and ensure safe construction for all, is the creation of neighborhoods that do not become known for their precariousness, but that are, rather, perceived as an extension of the existing ones, and as healthy developments of a sustainable city.

\section{FINAL CONSIDERATIONS}

Once having analyzed the matter of the fundamental right to housing, to a sustainable and qualified environment, the various constitutional and infraconstitutional regulations establish that public authorities should guarantee the correct synergy between the different governmental spheres in order to materialize the provision of appropriate technical assistance for the creation of sustainable and qualified cities and communities, designed for the future. 
It is true that in order to accomplish what the Law n. 11.888, of 2008, provides for it is required the participation of professional entities of architects and engineers, through a partnership agreement or covenant. This can be done with any of the federative entities in charge of the work execution. Financing must be obtained by Union for the States, by Union for Federal District, or directly with municipalities.

Although the law has been in force for some time, the problem still persists and it is observed that there is no adequate knowledge of the regulation, since it is not generally applied. Realization is verticalized in the terms provided by the Law. Thus, federal governing bodies have an overview. However, it is essential that federative entities participate in order to take into account the specificities of states and municipalities.

Initially, some projects were successful, according to information from the Secretaria Nacional de Habitação (Brazilian National Housing Secretariat), part of the former Ministry of Cities. However, given the vastness of the territory, the problem persists. The law could have included regional entities: metropolitan areas, urban agglomerations and micro regions to assist in selecting professionals and distributing technical assistance to the municipalities involved.

According to the research carried out by an experienced architect in the area, the program established by the Law was not fully adopted by the municipalities from Paraíba. Municipal laws were created, including in the capital of the State, João Pessoa; however, there was no positive repercussion. This gave birth to a new position adopted by CAU-PB, in order to enable local universities to develop an integration program prescribed in the regulation in question.

What can be said is that Law n. 11.888 , of 2008 , provided in its art. 5 the possibility of partnership with entities able to promote professional qualification, residency or university extension programs. As already mentioned in this paper, entities such as ATHIS have been spreading throughout the Brazilian territory and efforts are already being made in other states to involve architecture and urbanism councils in promoting the development of social projects.

\section{REFERENCES}

ATHIS. Fórum de Assistência Técnica e extensão universitária em habitação de interesse social: atuação integrada no espaço urbano. Available in < http://www.athis.org.br/sobre/ >. Accessed in May 3, 2019.

BENACCHIO, Marcelo and CASSETARI, Denis. Regularização fundiária urbana como efetivação do direito humano à moradia adequada. In "Regularização fundiária" (orgs) NALINI, José Renato and LEVY, Wilson. Rio de Janeiro: Forense, 2014, pp. 49 - 71.

BRAZIL. Law 10.257, of 29-6-2011. Available at: <www.planalto.org.br>. Accessed on: 21 Jul. 2019 .

BRAZIL. Law 12. 714, of 14-9-2012. Available at: <www.planalto.org.br>. Accessed on: 21 Jul. 2019 .

BRAZIL. Decreto $N^{\circ}$ 591, July 6, 1992. Atos Internacionais (International Pacto Internacional sobre Direitos Econômicos, Sociais e Culturais. Available at: <www. planalto.org.br>. Accessed on: 21 Jul. 2019. 
BRAZIL. Câmara dos Deputados. PEC N 6o1/1998. Available in:<http://www.camara.gov.br/ proposicoesWeb/fichadetramitacao?idProposicao=25007>. Accessed in: September 10, 2018.

BRAZIL. Lei $\mathrm{N}^{\circ}$ 11.888, December 24, 2008. Assure free public assistance in designing and constructing social-interest housing for low-income families and amends the Law No 11124, of June 16, 2005.Diário Oficial da República Federativa do Brasil, Brasília, DF, December 26, 2008 .

CAMACHO, Nadia de Oliveira. A utilização da Lei no 11.888/20o8 - Lei de Assistência Técnica Pública e Gratuita no programa minha casa minha vida: limites e possibilidades na pós-ocupação das unidades habitacionais. Thesis required to obtain the master's degree at the Federal University of Juiz de Fora. Advisor ABDALLA, José Gustavo Francis. Juiz de Fora-MG, 2016.

CARVALHO FILHO, José dos Santos. Comentários ao Estatuto da Cidade. São Paulo: Ed. Atlas, 2013.

COMPARATO, Fábio Konder. A afirmação histórica dos direitos humanos. 3. ed. São Paulo: Saraiva, 2004

CUT BRASIL. Assistência Técnica para a construção da moradia é direito do cidadão. Revista Projetar, Natal, Special Edition, [2009?]. Available in: <http://www.athis.org.br/wp-content/ uploads/2015/o9/2009_RevistaAT_FNA-CUT.pdf>. Accessed in: September 30, 2018.

IAB. Manual para a Implantação da Assistência Técnica Pública e Gratuita a Famílias de Baixa Renda para Projeto e Construção de Habitação de Interesse Social. Rio de Janeiro, 2010. Available in:<http://www.iab.org.br/sites/default/files/documentos/manualpara-implantacao-da-assistencia-tecnica-publica-e-gratuiata.pdf $>$. Accessed in: October 3, 2018 .

LEMOS J, Eloy Pereira e OLIVEIRA, Leonardo Alexandre Tadeu Constant de. Uma proposta de discussão da relação entre desenvolvimento humano e a eficácia horizontal dos direitos fundamentias preponderantes em alguns países democráticos ocidentais. Disponível em < https://periodicos.unipe.br/index.php/direitoedesenvolvimento/article/ view/571/497 > , acesso em 21.08.2019.

MORAES, A. P. de. Limites e potencialidades da assistência técnica pública e gratuita para projeto, construção e melhoria da habitação popular na cidade de Viçosa, MG. 2012. UFMV, 2012.

UNITED NATIONS. Universal Declaration of Human Rights. Paris, 1948. Available in: $<$ https://www.unicef.org/brazil/pt/resources_10133.htm>. Accessed in: September 3, 2018.

Pacto Internacional sobre Direitos Econômicos, Sociais e Culturais. New York, 1966. Available in: <http://www.unfpa.org.br/Arquivos/pacto_internacional.pdf >. Accessed in: September 5, 2018. 
NALINI, José Renato. Perspectivas da regularização fundiária. In "Regularização fundiária” (orgs) NALINI, José Renato and LEVY, Wilson. Rio de Janeiro: Forense, 2014, pp. 3- 10.

SANTOS, Jakeline Souza. Lei da assistência técnica pública e gratuita: um estudo de aplicação para municípios paraibanos. Thesis presented in the UFPB Architecture and Urbanism Graduate Program as a requirement to obtain a master's degree. UFPB, 2014.

SILVA, José Afonso da. Direito Ambiental Constitucional. 5. ed. São Paulo: Malheiros, 2004 .

TORRES, Ricardo Lobo. O direito ao mínimo existencial. Rio de Janeiro, Renovar, 2009, p. 192. 